\title{
ICTs and well-being: challenges and opportunities for tourism
}

\author{
Ulrike Gretzel $^{2} \cdot$ Uglješa Stankov ${ }^{1}$
}

Published online: 9 March 2021

(c) The Author(s), under exclusive licence to Springer-Verlag GmbH Germany, part of Springer Nature 2021

Well-being is becoming a central life goal that consumers increasingly seek to achieve through tourism experiences. Indeed, much evidence shows that consumers experience a higher sense of well-being prior and post their travels (Gilbert and Abdullah 2002; Vada et al. 2020). Simultaneously, information and communication technologies (ICTs) have rapidly penetrated consumers' everyday life, creating both positive and negative spillover effects (MacKay and Vogt 2012). As a result, ICTs have become paramount for the effective supply and delivery of tourism experiences by the various players within the tourism industry (Xiang 2018; Xiang and Fesenmaier 2020). In order to benefit from both aspects, namely the heightened interest in well-being and the proliferation of ICTs, tourism marketers and managers employ many technological innovations aiming to increase consumer well-being by making tourism experiences as enjoyable, relevant/personalized and friction-free as possible (Mizrachi and Gretzel 2020; Stankov et al. 2019; Stankov and Filimonau 2019).

There are also growing numbers of applications that try to help tourists be either more physically active, mentally engaged or more relaxed to harness the health benefits of vacations (Kang and Gretzel 2012; Stankov et al. 2020a, b). On the other hand, ICT use can also significantly disrupt tourism experiences and challenge wellbeing goals for the tourists and those around them (Stankov and Gretzel 2020). The relationship between ICT and well-being is thus not only crucial in everyday contexts but especially on vacation (Cai et al. 2019; Lau 2020; Stankov and Filimonau 2020). Whether the solutions are technological or involve-at least temporaryabandonment of technologies (Egger et al. 2020; Li et al. 2019), the connections

Uglješa Stankov

ugljesa.stankov@dgt.uns.ac.rs

Ulrike Gretzel

gretzel@usc.edu

1 Department of Geography, Tourism and Hotel Management, Faculty of Sciences, University of Novi Sad, Trg Dositeja Obradovica 3, Novi Sad 21000, Serbia

2 USC Center for Public Relations, Annenberg School of Communication and Journalism, University of Southern California, 3502 Watt Way, Los Angeles, CA 90089, USA 
between technology and well-being need to be more deeply explored in relation to tourism.

Consequently, this special issue of the Journal of Information Technology \& Tourism focuses on the challenges and opportunities ICT uses or practices create for well-being in tourism contexts. This special issue aims, on one hand, to elaborate on ICTs and their potential negative influence on tourism experiences and overall well-being. On the other hand, it seeks to recognize innovative ICTs and ongoing industry solutions to cope with well-being problems, or leverage IT uptake to create healthier and more beneficial experiences. These issues have become even more prominent in the current Covid-19 pandemic that has critically accelerated technology adoption while also challenging consumers' and the tourism industry's relations wit ICTs (Gretzel et al. 2020; Stankov et al. 2020a, b).

With this special issue, we highlight five contributions from authors who identify a series of issues related to different aspects of well-being closely related to ICT use in the tourism context. Authors in this special issue explore topics that directly influence primarily the physical well-being and health of ICT users, such as sports applications, and the ways ICT can make medical tourism more accessible. However, the authors also tackle physiological and psychological well-being aspects that should be adequately measured in the tourism context using more advanced approaches (in this case, with the employment of a synthetic reality space that simulates immersive tourism environments). In contrast, the complete absence of ICTs (under the light of stars during clear summer nights) is also explored here, as a way to facilitate wellbeing directly. The fifth contribution presents a general framework for understanding the issues of digital well-being in the tourism domain.

Well-being achieved through the use of sport-based applications is an important issue to be further explored in tourism studies, eigther from the perspective of positive outcomes for users or as a managerial issue for tourism providers. Perez-Aranda et al. (2019) explored attitudinal and norm-based factors that influence users' continuance intention towards sport applications as predictors of use in trips, and they provide readers with theoretical and managerial implications for the tourism industry.

Since good health and well-being go hand-in-hand, the tourism industry should be able to provide ways to make medical tourism more accessible and secure to consumers. In that sense, Parek et al. (2020) propose blockchain technology as a facilitator of medical tourism services for consumers. They explore how medical tourism could benefit from the increased disintermediation, transparency, and trust afforded by ICT use if the medical tourism offer was built on well-known strengths of blockchain technology.

Removing oneself from fast-growing environmental pollutants could generate positive outcomes on subjective well-being. Consumers are often unaware of the common pollutants they are already accustomed to, such as artificial lighting. Therefore, Bjelajac et al. (2020) emphasize the importance of dark skies and appropriate usage of ICTs in the nighttime hours to boost psychological health and well-being. They propose to utilize astronomy tourism as a new agenda for fighting light pollution exposure during vacations.

Still, to empirically prove positive outcomes of natural tourism settings, a new way of measuring should be employed in order to overcome common monitoring 
limitations. Therefore, Baldwin et al. (2020), investigate in their paper how an immersive, simulated tourism environment can be employed to measure tourism's potential to alleviate stress and enhance mood. The paper highlights the importance of data triangulation and rigor in testing. It also contributes to the growing literature on experimental research in tourism (Viglia and Dolnicar 2020). Importantly, it also hints at the possibility to use technology to successfully simulate multisensory tourism experiences that increase well-being more effectively than traditional leisure pursuits, such as watching TV.

As seen just from these four different perspectives on well-being and ICT published in this special issue, and not mentioning other outlets (Clarke et al. 2018), the paths for further investigation of the topic are diverse. This also creates many new challenges and opportunities in the tourism domain. If we look just at digital well-being, a set of new roles and responsibilities emerges for the tourism industry. Thus, special issue editors Stankov and Gretzel (2021) conceptualize three general directions in the tourism domain, grouped around the need for adopting digital wellbeing philosophy in tourism, setting up new policies within the fabric of tourism, and developing tactics for designing novel services and experiences.

Together, all five papers imply that the impacts of technology on tourism experiences (both negative and positive) should be investigated from a well-being perspective. This requires sound conceptualizations of short-term and long-term well-being, and the development of innovative measurement approaches. The research in this special issue also suggests that technology and experience design in tourism should have an explicit focus on well-being that goes beyond common usability concerns. Last but not least, fostering physical and mental well-being through or despite the emergence of evermore sophisticated devices and applications should be an explicit goal for tourism providers and destinations. How ICTs can be implemented to promote and measure well-being in tourism settings is, thus, a topic that will continue to gain in importance.

\section{References}

Baldwin J, Haven-Tang C, Gill S, Morgan N, Pritchard A (2020) Using the perceptual experience laboratory (PEL) to simulate tourism environments for hedonic wellbeing. InfTechnol Tour. https://doi. org/10.1007/s40558-020-00179-x

Bjelajac D, Đerčan B, Kovačić S (2020) Dark skies and dark screens as a precondition for astronomy tourism and general well-being. InfTechnol Tour. https://doi.org/10.1007/s40558-020-00189-9

Cai W, McKenna B, Waizenegger L (2019) Turning it off: emotions in digital-free travel. J Travel Res. https://doi.org/10.1177/0047287519868314

Clarke A, Azara I, Michopoulou E (2018) The vision and the mission of the International Journal of Spa and Wellness. Int J Spa Wellness 1(1):1-3. https://doi.org/10.1080/24721735.2018.1438571

Egger I, Lei SI, Wassler P (2020) Digital free tourism—an exploratory study of tourist motivations. Tour Manag 79:104098-104098. https://doi.org/10.1016/j.tourman.2020.104098

Gilbert D, Abdullah J (2002) A study of the impact of the expectation of a holiday on an individual's sense of well-being. J Vacat Mark 8(4):352-361. https://doi.org/10.1177/135676670200800406

Gretzel U, Fuchs M, Baggio R, Hoepken W, Law R, Neidhardt J, Pesonen J, Zanker M, Xiang Z (2020) e-Tourism beyond COVID-19: a call for transformative research. InfTechnol Tour 22(2):187-203. https://doi.org/10.1007/s40558-020-00181-3 
Kang M, Gretzel U (2012) Effects of podcast tours on tourist experiences in a national park. Tour Manag 33(2):440-455. https://doi.org/10.1016/J.TOURMAN.2011.05.005

Lau A (2020) New technologies used in COVID-19 for business survival: Insights from the Hotel Sector in China. InfTechnol Tour 22(4):497-504. https://doi.org/10.1007/s40558-020-00193-z

Li J, Pearce P, Chen T (2019) New connections from being disconnected; digital free tourism and rewarding experiences. CAUTHE 2019: sustainability of tourism, hospitality and events in a disruptive digital age: proceedings of the 29th annual conference, 149-159

MacKay K, Vogt C (2012) Information technology in everyday and vacation contexts. Ann Tour Res 39(3):1380-1401

Mizrachi I, Gretzel U (2020) Collaborating against COVID-19: bridging travel and travel tech. InfTechnol Tour 22(4):489-496. https://doi.org/10.1007/s40558-020-00192-0

Parekh J, Jaffer A, Bhanushali U, Shukla S (2020) Disintermediation in medical tourism through blockchain technology: an analysis using value-focused thinking approach. InfTechnol Tour. https://doi. org/10.1007/s40558-020-00180-4

Perez-Aranda J, González Robles EM, Urbistondo PA (2019) Sport-related physical activity in tourism: an analysis of antecedents of sport based applications use. InfTechnol Tour. https://doi.org/10.1007/ s40558-019-00161-2

Stankov U, Filimonau V (2019) Reviving calm technology in the e-tourism context. ServInd J 39(56):343-360. https://doi.org/10.1080/02642069.2018.1544619

Stankov U, Filimonau V (2020) Technology-assisted mindfulness in the co-creation of tourist experiences. In: Xian Z, Fuchs M, Gretzel U, Höpken W (eds) Handbook of e-tourism. Springer, Berlin. https://doi.org/10.1007/978-3-030-05324-6

Stankov U, Gretzel U (2020) Tourism 40 technologies and tourist experiences: a human-centered design perspective. InfTechnol Tour. https://doi.org/10.1007/s40558-020-00186-y

Stankov U, Gretzel U (2021) Digital well-being in the tourism domain: mapping new roles and responsibilities. Inf Technol Tour. https://doi.org/10.1007/s40558-021-00197-3

Stankov U, Filimonau V, Slivar I (2019) Calm ICT design in hotels: a critical review of applications and implications. Int J HospManag 82:298-307. https://doi.org/10.1016/j.ijhm.2018.10.012

Stankov U, Filimonau V, Gretzel U, Vujičić MD (2020a) E-mindfulness-the growing importance of facilitating tourists' connections to the present moment. J Tour Futur. https://doi.org/10.1108/ JTF-11-2019-0135

Stankov U, Filimonau V, Vujičić MD (2020b) A mindful shift: an opportunity for mindfulness-driven tourism in a post-pandemic world. Tour Geogr. https://doi.org/10.1080/14616688.2020.1768432

Vada S, Prentice C, Scott N, Hsiao A (2020) Positive psychology and tourist well-being: a systematic literature review. Tour ManagPerspect 33:100631. https://doi.org/10.1016/j.tmp.2019.100631

Viglia G, Dolnicar S (2020) A review of experiments in tourism and hospitality. Ann Tour Res 80:102858

Xiang Z (2018) From digitization to the age of acceleration: on information technology and tourism. Tour ManagPerspect 25:147-150. https://doi.org/10.1016/J.TMP.2017.11.023

Xiang Z, Fesenmaier DR (2020) Travel information search. In: Xiang Z, Fuchs M, Gretzel U, Höpken W (eds) Handbook of e-tourism. Springer, Berlin, pp 1-20. https://doi.org/10.1007/978-3-030-05324 $-6 \_55-1$

Publisher's Note Springer Nature remains neutral with regard to jurisdictional claims in published maps and institutional affiliations. 